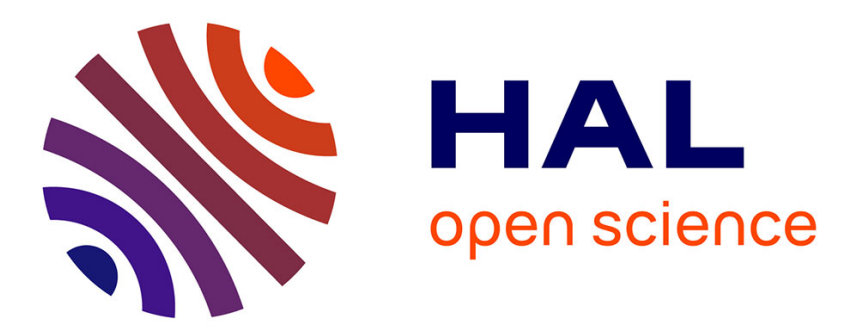

\title{
Dose repartition in alveoli, alveolar ducts and bronchi of rats exposed to radon and its progeny, preliminary results
}

Michèle Bisson, P. Fritsch, J.P. Morlier, P. Sabattie, J. Tredaniel, H.

Richard-Le Naour, G. Monchaux

\section{To cite this version:}

Michèle Bisson, P. Fritsch, J.P. Morlier, P. Sabattie, J. Tredaniel, et al.. Dose repartition in alveoli, alveolar ducts and bronchi of rats exposed to radon and its progeny, preliminary results. International Symposium on the Natural Radiation Environment, Jun 1995, Montréal, Canada. ineris-00971951

\section{HAL Id: ineris-00971951 \\ https://hal-ineris.archives-ouvertes.fr/ineris-00971951}

Submitted on 3 Apr 2014

HAL is a multi-disciplinary open access archive for the deposit and dissemination of scientific research documents, whether they are published or not. The documents may come from teaching and research institutions in France or abroad, or from public or private research centers.
L'archive ouverte pluridisciplinaire HAL, est destinée au dépôt et à la diffusion de documents scientifiques de niveau recherche, publiés ou non, émanant des établissements d'enseignement et de recherche français ou étrangers, des laboratoires publics ou privés. 


\section{DOSE REPARTITION IN ALVEOLI, ALVEOLAR DUCTS AND BRONCHI OF RATS EXPOSED TO RADON AND ITS PROGENY, PRELIMINARY RESULTS.}

Bisson M. (1), Fritsch P. (2), Morlier J.P. (3), Sabattié P. (3), Trédaniel J. (4), Richard-Le Naour H. (2), and Monchaux G.(3)

1. Laboratoire de Biochimie et de Toxicologie in vitro, TEC/ INERIS, BP2, 60550 VERNEUIL EN HALATTE, FRANCE.

2. Laboratoire de Radiotoxicologie, DPTE/ DSV/ CEA, BP12, 91680 BRUYERES LE CHATEL, FRANCE.

3. Laboratoire de Cancérogenèse Expérimentale, DPTE/ DSV/ CEA, BP6, 92265 FONTENAY AUX ROSES, FRANCE.

4. Service de Pneumologie, Hôpital Saint-Louis, 75010 PARIS, FRANCE.

\section{Abstract}

Rats were exposed to $2 \mathrm{ppm}$ ozone for 5 hours to increase micronuclei formation in the different lung compartments one week after local irradiation. Animals were exposed to either radon and its progeny (300 and 1000 WLM) or local lung external irradiation using gamma rays from cobalt-60 (7.5 Gy). Animals were administered 5-bromo 2'deoxyuridine 18 and 12 hours before to label post replicative cells. They were killed 36,48 and 60 hours after the beginning of the ozone exposures. Alveolar macrophages (AM) were recovered by lavage of the left lobe and the right lobes were fixed for histological studies using confocal microscopy.

Micronuclei measurements in AM did provide only mean dose estimate to the deep lung. Histological observations showed a nearly homogeneous irradiation by gamma rays whereas, heterogeneous irradiation seemed to occur after radon exposure with a gradual dose increase from alveoli to bronchi.

Confocal microscopy/ Micronuclei/ Radon/ Ozone/ Pulmonary epithelial cells/ Alveolar macrophages/ Rats/ Gamma rays/ 


\section{Introduction}

Recently, micronuclei scoring has been performed to estimate doses delivered to the lungs after heterogenous irradiation induced after inhalation of radon and its progeny. These studies were limited to the deep lung after either extraction of alveolar macrophages (AM) by lavage (Taya et al., 1994, Johnson and Newton, 1994) or enzymatic dissociation of lung cells to initiate fibroblast cultures (Khan et al., 1994). Dose estimates were performed after comparison with micronuclei formation induced in vitro by irradiation with alpha particles.

We have previously shown that, after irradiation, micronuclei formation can be greatly increased by an acute ozone exposure which transiently stimulates lung cell proliferation, mainly for epithelial cells and AM (Bisson et al 1994), we have also developed an experimental procedure to score micronuclei in post-replicative cells on lung thick sections by scanning confocal microscopy (Bisson et al., 1995).

The aim of this study was to provide qualitative and quantitative results to compare micronuclei induction in AM after radon and gamma ray exposure and to estimate dose distribution within the different lung compartments. 


\section{Material and methods}

Male Sprague-Dawley rats (OFA, Iffa Credo, France), were used at 3 months of age. Five groups of animals were studied : rats exposed 1) to ozone alone, 2) to gamma rays from cobalt-60 and ozone, 3) to radon and ozone, 4) to radon alone and 5) unexposed controls. The irradiations were performed one week before the ozone exposure.

Ozone exposure was whole-body performed in a Hazleton inhalation chamber. Ozone was produced by passing pure oxygen through a silent electric arc-type ozoniser (WALLACE and TIERNAN BA 023012). The gas mixture was diluted with air to obtain a final concentration of 2 ppm which was monitered continously in the chamber with an analyser ( $\mathrm{O}_{3} 43 \mathrm{M}$, Environnement S.A.). The duration of exposure was 5 hours (Trédaniel et al., 1994).

Whole-body exposure to radon and its progeny was performed during 24 hours in the Razes facility to obtain either 300 or 1000 WLM (equilibrium factor : 0.80, "unattached" fraction : 0.08) (Monchaux et al., 1994). 7.5 Gy local lung gamma irradiation was performed using cobalt-60 at a dose rate of 1 $\mathrm{Gy} / \mathrm{min}$.

5-bromo 2'-deoxyuridine (BrdU) $(25 \mathrm{mg} / \mathrm{kg})$ and deoxycytidine $(10 \mathrm{mg} / \mathrm{kg})$ were administered 18 and 12 hours before killing to label cells which synthesize DNA. After pentobarbital anaesthesia, the left lung was lavaged, cells were counted and cytospin were observed after Giemsa staining, the right lobes were fixed in $4 \%$ buffered paraformaldehyde for 3 days. Thick cryostat sections $(80 \mu \mathrm{m})$ of fixed tissue were stained by a primary antibody mouse anti BrdU and 
a secondary antibody: goat anti mouse FITC labelled. Cells were counterstaining by propidium iodine. Labelled cells were observed by scanning confocal microscopy as previously described (Bisson et al., 1995).

\section{Results}

In each group of irradiated rats, a nearly two-fold increase in the number of extracted AM was observed from 36 to 60 hours after the beginning of ozone exposure. This increase was similar to that observed in unirradiated controls. Figure 1 shows the percentage of AM with micronuclei (MiAM) in irradiated rats either exposed or unexposed to ozone. In control rats unexposed to ozone, MiAM was $0.2 \% \pm 0.1$ which was not significantly modified by the ozone exposure. In irradiated rats unexposed to ozone, similar MiAM were observed for 7.5 Gy and 1000 WLM but, the ozone exposure induced a larger increase of MiAM for 7.5 Gy than for 1000 WLM. For all post ozone exposure times studied, MiAM induced after 300 WLM was always less than that induced by 1000 WLM.

Observations by scanning confocal microscopy of micronuclei in alveolar tissue seemed to be in agreement with results obtained in extracted AM. By contrast, in the bronchial epithelium, the fraction of cells with micronuclei appeared similar for $7.5 \mathrm{~Gy}$ and $300 \mathrm{WLM}$ and most of the cells had only one micronucleus. A larger fraction of micronucleated bronchial cells seemed to occur for 1000 WLM than for $7.5 \mathrm{~Gy}$ and 300 WLM. Because most micronucleated cells after 1000 WLM contained more than 1 micronucleus, we have measured in one animal the number of micronuclei per micronucleated cells in different lung compartments. Results are shown in figure 2. About $50 \%$ 
of micronucleated alveolar cells contained only one micronucleus whereas, in alveolar ducts and in bronchi, this population corresponded to $43 \%$ and $33 \%$ of the total micronucleated cells respectively. The percentage of cells containing 4 micronuclei was higher in bronchi than in alveolar ducts or in alveoli, $25 \%$, $10 \%$ and $5 \%$ respectively .

\section{Discussion}

This study on AM confirms that ozone exposure increases micronuclei formation in irradiated rats and could be a useful tool for biological dosimetry (Bisson et al., 1994). The observed results did not provide an accurate value of dose equivalent for radon exposure but were consistant with that previously reported (1 WLM $=0.8 \mathrm{mGy}$ alpha) (Khan et al., 1994) taking into account for micronuclei induction a relative biological effectiveness of 10 for alpha versus gamma irradiation (Brooks et al., 1994). Further studies are in progress to determine dose effect relationship for both homogeneous gamma irradiation and heterogeneous radon exposures, and the evolution of cellular alterations (spontaneous and ozone induced AM proliferation, micronucleated AM and multinucleated $\mathrm{AM}$ ) as a function of post-irradiation time.

Although only preliminary results were obtained, the histological study provides new data for dose distribution estimate within lung tissues. Under the experimental exposure used, i.e. high equilibrium factor and low "unattached" fraction, a gradual increase of doses appeared to be delivered from the most distal lung to the bronchi. Thus, the maximal dose might not be delivered to the main target area for lung tumour induction which is located in the bronchiolo-alveolar junction (Poncy et al., 1992) or in alveoli (Cross et al., 1984). 
These results are conflicting with dose repartition reported using mathematical model (Hofmann et al., 1993). Further studies are in progress to provide more complete quantitative results and to determine the effect of exposure conditions to radon and its progeny on dose distribution in the different lung compartments.

\section{Acknowledgement}

This work was supported by CEC contract FI3PCT920021.

\section{References}

M. Bisson, C.G. Collier, J.L. Poncy, A. Taya, J.P. Morlier, J. Strong, S. Baker, G. Monchaux and P. Fritsch, Biological dosimetry in different compartments of the respiratory tract after inhalation of radon and its daughters, Radiat. Prot. Dosim., 56 (1994) 89-92.

M. Bisson, P. Fritsch, J.P. Morlier, H. Richard-Le Naour, P.L. Sabattié and G. Monchaux, Micronuclei scoring in irradiated lungs by confocal microscopy, submitted to Scanning Microscopy, (1995).
A.L. Brooks, M.A. Khan, A. Duncan, R.L. Buschbom, R.F. Jostes and F.T. Cross, Effectiveness of radon relative to acute $60 \mathrm{Co} \gamma$-rays for induction of micronuclei in vitro and in vivo. Int. J. Radiat. Biol., 66 (1994) 801-808. 
F.T. Cross, R.F. Palmer, G.E. Dagle, R.H. Busch and R.L. Buschbom, Influence of radon daughters exposure rate, unattachment fraction, and disequilibrium on occurence of lung tumors. Radiat. Prot. Dosim., 7 (1984) 381-384.

W. Hofmann, M.G. Ménache and R.C. Graham, Radon progeny dosimetry in the rat lung. Health Phy., 64 (1993) 279-290.

N.F. Johnson, G.J. Newton, Estimation of the dose of radon progeny to the peripheral lung and the effect of exposure to radon progeny on the alveolar macrophages, Radiat. Res., 139 (1994) 163-169 .

M.A. Khan, F.T. Cross, R. Jostes, E. Hui, J.E. Morris and A.L. Brooks, Micronuclei induced by radon and its progeny in deep-lung fibroblasts of rats in vivo and in vitro. Radiat. Res., 139 (1994) 53-59.

G. Monchaux, J.P. Morlier, M. Morin, J. Chameaud, J. Lafuma and R. Masse, Carcinogenic and cocarcinogenic effects of radon and radon daughters in rats: an overview of 20 years of study. Environ. Health Perspect., 102 (1994) 64-73.

J.L. Poncy, P. Laroque, P. Fritsch, G. Monchaux, J. Chameaud and R. Masse, An experimental two-stage rat model of lung carcinoma initiated by radon exposure. In: Indoor radon and lung cancer: reality or myth? F.T. Cross Eds, Batelle Press, Colombus (1992) p803-820.

A. Taya, A. Morgan, S.T. Baker, J.A.H. Humphreys, M. Bisson and C.G. Collier, Changes in the rat lung after exposure to radon and its progeny: effects on incorporation of bromodeoxyuridine in the epithelial cells and on the 
incidence of nuclear aberrations in alveolar macrophages, Radiat. Res., 139 (1994) 170-177. 


\section{CAPTIONS}

Figure 1: Evolution of micronucleated $A M$ as the function of time following acute ozone exposure (mean values $\pm \mathrm{sd}$ for at least 4 animals per group).

Figure 2: Distribution of the number of micronuclei per cell in the different lung compartment (animal exposed to ozone one week after 1000 WLM and killed 60 hours later).

Figure 3: Micronuclei within post-replicative cells of the bronchiolar epithelium. Observation performed by confocal microscopy after an exposure to 300 WLM and 48 hours after the ozone exposure (step between 2 successive view $2 \mu \mathrm{m})$. 


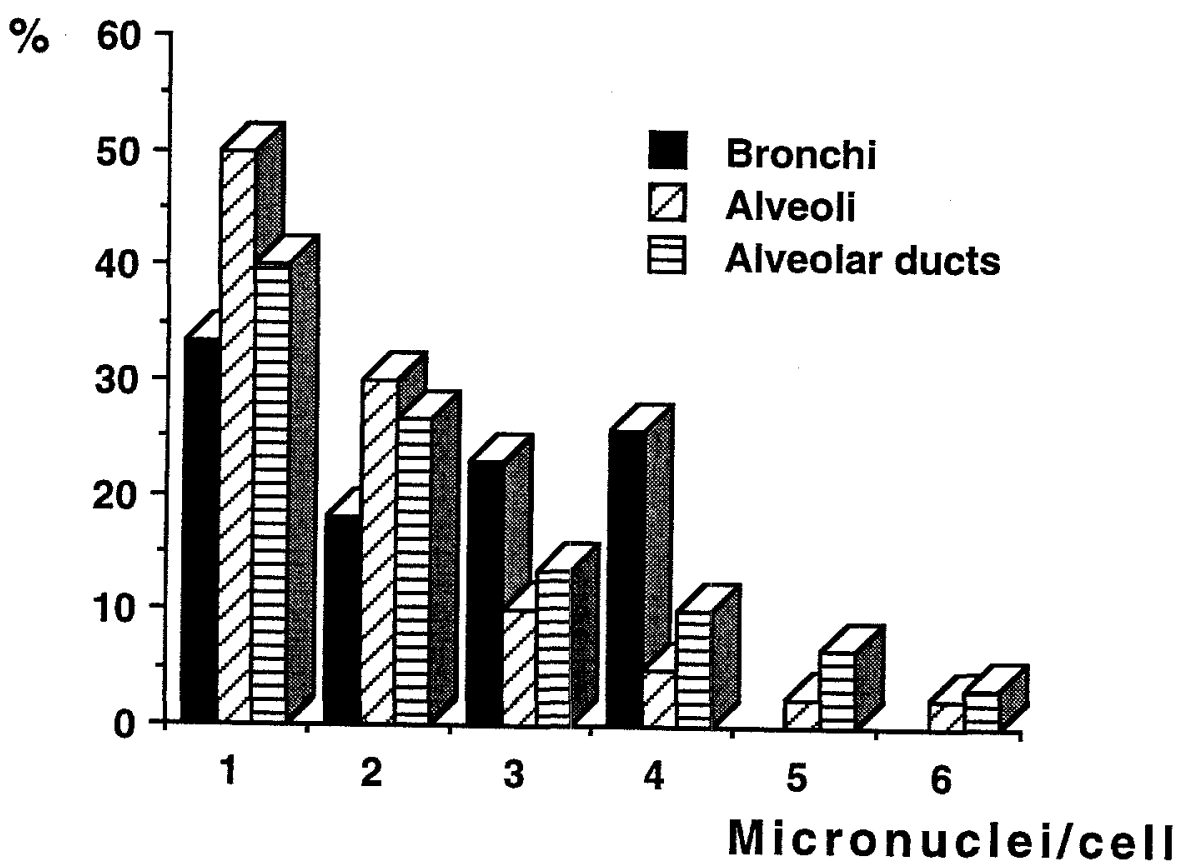




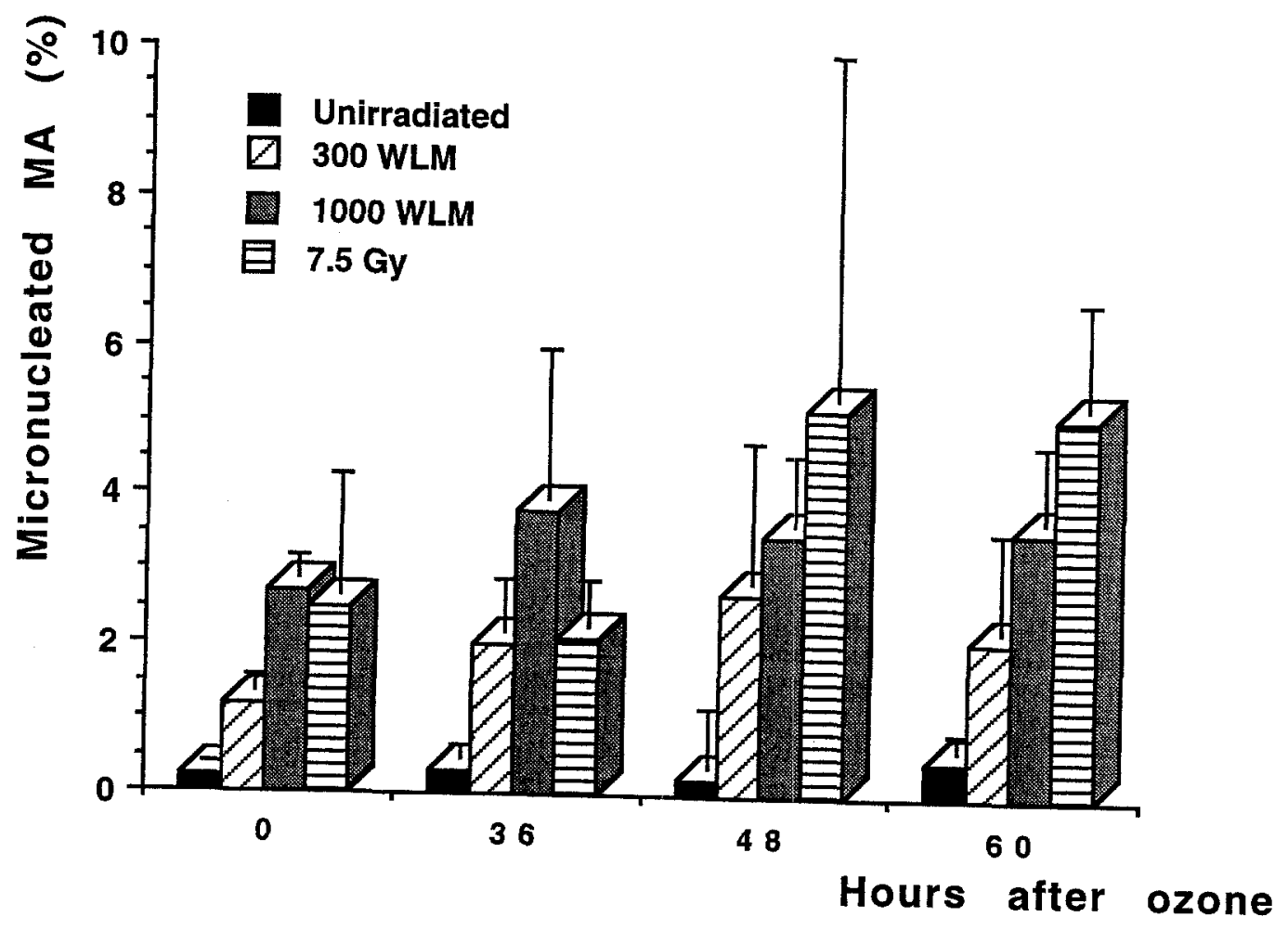

